\title{
STRATEGI ADAPTASI PETANI PADI ORGANIK DI ERA COVID-19 (Studi Kasus di Kelompok Tani Cidahu, Desa Mekarwangi Kecamatan Cisayong Kabupaten Tasikmalaya)
}

\section{ORGANIC RICE FARMER ADAPTATION STRATEGY IN THE ERA COVID-19 (Case Study in Cidahu Farmer Group, Mekarwangi Village, Cisayong District, Tasikmalaya Regency)}

\author{
Devita Rusdianti*, Yayat Sukayat \\ Program Studi Agribisnis, Fakultas Pertanian, Universitas Padjadjaran \\ *Email: devitarsdnti@mail.unpad.ac.id \\ (Diterima 18-1-2021; Disetujui 26-1-2021)
}

\begin{abstract}
ABSTRAK
Kelompok tani Cidahu merupakan kelompok tani yang mulai membudidayakan padi organik sejak tahun 2005. Poktan Cidahu menjalin hubungan kemitraan dengan Gapoktan Simpatik sebagai kelembagaan formal yang menaungi petani dalam memasarkan hasil produksi padi organik untuk pasar domestik maupun pasar ekspor. Perubahan permintaan dari Gapoktan Simpatik kepada petani di tengah Pandemi Covid-19 menyebabkan beberapa perubahan dalam aktivitas usahatani dan tindakan pemenuhan kebutuhan rumah tangga petani. Tujuan dari penelitian ini adalah mendeskripsikan strategi adaptasi yang dilakukan oleh petani padi organik di era Covid-19. Metode penelitian yang digunakan adalah kualitatif dengan pendekatan studi kasus di Kelompok Tani Cidahu. Teknik Pengumpulan data yang digunakan yaitu in depth interview, wawancara online, observasi, dan dokumentasi. Analisis data dalam penelitian ini menggunakan teknik pengumpulan data, reduksi data, penyajian data, dan penarikan kesimpulan. Hasil penelitian ini menunjukan bahwa petani melakukan upaya-upaya untuk melakukan penyesuaian dengan perubahan yang diakibatkan Pandemi Covid-19 dengan melakukan strategi aktif, pasif, jaringan dan strategi aktivitas lapangan. Berdasarkan penelitian ini menurut petani dengan melakukan strategi tersebut mampu meminimalisir petani untuk tidak melewati batas subsistensi, mampu memenuhi kebutuhan rumah tangga dan beradaptasi dengan situasi di tengah Pandemi Covid-19.
\end{abstract}

Kata Kunci: Covid-19, Strategi Adaptasi Petani Padi Organik

\section{ABSTRACT}

Cidahu farmer group is a farmer group that started cultivating organic rice since 2005. Poktan Cidahu has a partnership with Gapoktan Simpatik as a formal institution that houses farmers in marketing organic rice production for domestic and export markets. Changes in demand from Simpatik Farmers Association to Farmers in the midst of the Covid-19 Pandemic led to several changes in farming activities and actions to fulfill the needs of farmer households. The purpose of this study is to describe the adaptation strategies carried out by organic rice farmers in the Covid19 era. The research method used is qualitative with a case study approach in the Cidahu Farmer Group. Data collection techniques used are in-depth interviews, online interviews, observation, and documentation. Data analysis in this study used data collection techniques, data reduction, data presentation, and drawing conclusions. The results of this study indicate that farmers are making efforts to make adjustments to the changes caused by the Covid-19 Pandemic by implementing active, passive, network and field activity strategies. Based on this research, according to farmers, by implementing this strategy, they are able to minimize farmers from exceeding subsistence limits, be able to fulfill household needs and adapt to the situation amid the Covid-19 Pandemic.

Keywords: Covid-19, Organic Rice Farmer Adaptation Strategies 


\section{PENDAHULUAN}

Kabupaten Tasikmalaya merupakan daerah yang mampu memproduksi dan membudidayakan padi organik sejak tahun 2006 serta menjadi sentra produksi beras organik yang mampu menembus pasar ekspor. Hasil produksi yang diolah menjadi beras organik ini mampu menembus pasar ekspor yaitu ke negara Amerika, Malaysia, Jerman, Singapura, Dubai, Belanda, Italia dan Belgia (Istiqomah et al, 2019). Kecamatan Cisayong melalui Gapoktan Simpatik merupakan pemasok utama kebutuhan ekspor karena mampu memproduksi ratarata sebanyak 7,9 ton per hektar dan menjadi satu-satunya daerah yang memiliki sertifikasi organik murni.(Istiqomah et al, 2019). Kemampuan ekspor dari Gapoktan Simpatik ini menjadi potensi yang baik bagi perkembangan ekspor produk beras organik Indonesia, namun saat ini adanya Pandemi Covid-19 berpotensi menghambat aliran rantai pasok padi organik.

Produk beras organik dapat dikategorikan sebagai golongan pasar terstruktur. Hal ini terlihat dari ciri pasar terstruktur yang memberikan spesifikasi kepada produk yang masuk, misalnya tentang spesifikasi kualitas dan ketersediaan pasokan barang yang bersifat kontinu. Aliran rantai pasok beras organik melibatkan beberapa pihak seperti petani yang tergabung dalam kelompok tani, lalu industri pengolahan, retailer beras dan konsumen akhir. Karakteristik pasar beras organik yang terstruktur ini menjadi tantangan tersendiri dalam meraba kondisi pasar di tengah Pandemi Covid-19 yang terjadi pasalnya hadirnya Pandemi Covid-19 mempengaruhi berbagai aspek termasuk salah satunya perubahan pola konsumsi masyarakat dan pendistribusian hasil produksi.

Pada tingkat industri pengolahan atau tepatnya di Gapoktan Simpatik terdapat beberapa kendala yang diakibatkan Pandemi Covid-19. Terbatasnya lembaga pemasaran khusus di Kecamatan Cisayong tepatnya di Kampung Cidahu yang membeli beras organik dari hasil petani menjadikan Gapoktan Simpatik sebagai satu-satunya lembaga pemasaran yang membeli beras organik secara formal. Kondisi pedagang yang jumlahnya terbatas dan bersifat individualis dapat mempengaruhi struktur pasar (Setiawan, 2015), hal ini menyebabkan beras organik berada di pasar terstruktur. 
Fakta bahwa Gapoktan Simpatik menjadi lembaga pemasaran tunggal yang bersifat formal, menjadikan petani di kelompok tani Cidahu bergantung pada daya serap dari Gapoktan Simpatik dalam membeli hasil panen dan juga sebagai penyedia sarana produksi pertanian dalam proses budidaya padi organik. Namun, dengan kondisi pasar yang tidak pasti menyebabkan beberapa kendala dalam proses jual beli dengan petani. Salah satu hambatan distribusi yang terjadi pada Gapoktan Simpatik adalah ketersediaan dan keterlambatan pengiriman benih yang berakibat pada keterlambatan dalam melakukan penanaman padi organik pada tingkat petani, sehingga petani harus menunggu ketersediaan benih dari Gapoktan Simpatik dalam waktu yang tidak pasti. Pada proses penyerapan hasil produksi dari petani, Gapoktan Simpatik mengalami penurunan dalam membeli hasil panen. Hal ini disebabkan karena terdapat permasalahan pada pasar domestik dan pasar ekspor. Permasalahan pasar ekspor terjadi kendala, terhitung sejak tahun 2019 Gapoktan Simpatik tidak lagi melakukan aktivitas ekspor dalam memasarkan hasil produksi beras organik. Meskipun permintaan pasar domestik tetap ada namun kekosongan permintaan di pasar ekspor menunjukkan dampak yang signifikan terhadap permintaan beras organik kepada kelompok tani Cidahu. Serapan pasar domestik yang terbatas akibat produk organik memiliki pasar yang tersegmentasi ditambah dengan kondisi daya beli yang menurun dan tidak lagi melakukan ekspor menyebabkan kelesuan pada aktivitas jual beli di tingkat Gapoktan Simpatik yang berakibat pada penyerapan hasil produksi padi organik kelompok tani Cidahu.

Perubahan kondisi pada tingkat konsumen ini tentunya akan berdampak pada perilaku petani dalam merespons permintaan. Selain itu, keterbatasan distribusi menjadi salah satu hal yang dapat menghambat aktivitas petani dalam memenuhi permintaan konsumen, sehingga petani harus mengambil tindakan tertentu agar mampu beradaptasi dengan perubahan situasi yang diakibatkan Pandemi Covid-19 melalui strategi-strategi yang dipilih untuk menjaga eksistensi ketersediaan beras organik dan untuk melakukan pemenuhan kebutuhan rumah tangga di Kampung Cidahu, Kecamatan Cisayong, Kabupaten Tasikmalaya, Jawa barat. 


\section{METODE PENELITIAN}

Penelitian ini dilakukan di Kampung Cidahu, Desa Mekarwangi, Kecamatan Cisayong, Kabupaten Tasikmalaya, Jawa Barat. Pendekatan penelitian ini adalah dengan penelitian kualitatif menggunakan pendekatan interpretatif yang berusaha untuk menggali wawasan tentang mekanisme dan perilaku individu atau kelompok secara spesifik ketika mengalami fenomena sosial tertentu melalui pengalaman subjektif. Subjek penelitian ini adalah anggota kelompok tani Cidahu dan objek yang dianalisis adalah aktivitas dan tindakan yang dipilih petani padi organik dalam melakukan strategi adaptasi di era Covid-19 di Kampung Cidahu, Desa Mekarwangi, Kecamatan Cisayong, Kabupaten Tasikmalaya.

Analisis deskriptif merupakan metode yang paling tepat digunakan dalam penelitian ini karena metode ini menggunakan deskripsi kata dan gambar untuk mempelajari tingkah laku individu atau kelompok dan realitas perspektif subjek. Tipe penelitian ini adalah deskriptif kualitatif karena bertujuan untuk mendeskripsikan, menguraikan dan menggambarkan tentang strategi adaptasi petani secara mendalam.
Peneliti di bidang sosial memiliki sejumlah strategi yang berbeda dalam melakukan teknik pengumpulan data. Menurut Cavan (1977), terdapat dua kategori dalam proses pengumpulan data, yaitu melalui data primer dan data sekunder. Kedua jenis data tersebut memiliki perbedaan penting dimana data primer merupakan data yang orisinal dan bersifat factual; sedangkan data sekunder merupakan data yang berasal dari interpretasi dan analisis data primer. Data primer dikumpulkan melalui in depth interview, observasi, dan wawancara online. Data sekunder yang digunakan dalam penelitian ini berasal dari arsip data yang dimiliki oleh sekretaris desa, penelitian terdahulu, dan portal-portal web yang menyediakan data mengenai kebutuhan penelitian. Teknik analisis kualitatif menurut Miles dan Hubberman dalam Sugiyono (2016) ada beberapa tahapan yaitu pengumpulan data, reduksi data, penyajian dana dan penarikan kesimpulan.

HASIL DAN PEMBAHASAN

Gambaran Umum Tempat Penelitian

Tasikmalaya memiliki 39 kecamatan, salah satunya adalah kecamatan Cisayong. Secara geografis Kecamatan Cisayong memiliki luas 
wilayah dengan luas $2.712,51 \mathrm{~km}^{2}$ dan ketinggian rata-rata $570 \mathrm{~m}$ di atas permukaan laut. Kecamatan Cisayong terbagi menjadi 13 desa, salah satunya adalah Desa Mekarwangi.

Desa Mekarwangi terletak di Jalan Raya Ciawi Km 13, merupakan salah satu desa di Kecamatan Cisayong, Kabupaten Tasikmalaya, Jawa Barat yang terdaftar secara administratif, tepatnya berada di titik koordinat $108.18814^{\circ}$ E. Secara geografis Desa Mekarwangi berada di ketinggian $320 \mathrm{mdpl}$ dari permukaan laut. Desa Mekarwangi memiliki total luas daerah seluas 195 ha, luas wilayah tersebut dibagi menjadi 4 kedusunan. Penyebaran luas wilayah tersebut dapat terlihat dari Tabel 1.

Pemberian nama dusun ini sekaligus menjadi nama-nama kelompok tani yang tersebar di Desa Mekarwangi. Luas total lahan pertaniannya sebesar 115 ha. Desa ini menjadi daerah penghasil padi organik di Kecamatan Cisayong. Dusun Cidahu dengan nama kelompok tani Cidahu merupakan satu-satunya dusun yang memiliki sertifikasi organik dan tergabung dalam Gapoktan Simpatik di wilayah Kecamatan Cisayong.
Tabel 1 Luas Wilayah Desa Mekarwangi

\begin{tabular}{clccc}
\hline No & Dusun & Luas (ha) & RW & RT \\
\hline 1. & Cibodas Pasar & 48,7 & 3 & 9 \\
2. & Kebon Bencoy & 50,3 & 3 & 9 \\
3. & Cidahu & 50,5 & 3 & 9 \\
4. & Langkob & 45,5 & 2 & 5 \\
\hline & Total & 195 & 11 & 32 \\
\hline
\end{tabular}

\section{A. Kondisi Sosial Ekonomi Dusun Cidahu}

\section{Kependudukan}

Saat ini penduduk dimaknai sebagai subjek pembangunan sekaligus menjadi objek pembangunan, artinya sebagai subjek pembangunan perlu ada peningkatan kualitas sumberdaya manusia dan sebagai objek pembangunan, penduduk perlu dikendalikan jumlahnya. Menurut data yang diperoleh dari BPS, menunjukkan bahwa jumlah penduduk di Desa Mekarwangi sampai pada tahun 2018 mencapai 4.517 jiwa atau sebanyak 3,65 per KK. Populasi ini memiliki kepadatan penduduk sebesar 2,52 jiwa/km2.

\section{a. Penduduk Berdasarkan Umur Jenis Kelamin \\ Proporsi pembagian penduduk} menurut jenis kelamin ini 2.299 jiwa dengan persentase sebesar 51\% untuk laki-laki, sedangkan jumlah penduduk perempuan sebesar 2.218 jiwa dengan persentase sebesar $49 \%$ untuk perempuan. Hal ini mengindikasikan bahwa penduduk Desa Mekarwangi 
didominasi oleh laki-laki dibandingkan jumlah penduduk perempuan. Berdasarkan data yang diperoleh dari kantor Desa Mekarwangi mayoritas penduduk Desa Mekarwangi berada di golongan umur produktif dengan rentang usia 15-65 tahun, penyebaran komposisi golongan umur ini jika dipersentasekan sebesar $74 \%$ berusia antara $15-65$ tahun, kemudian sebesar $17 \%$ berada di golongan usia di bawah 15 tahun, dan yang terakhir adalah golongan yang berusia di atas 65 tahun dengan persentase sebesar $9 \%$.

\section{b. Penduduk Berdasarkan Tingkat Pendidikan}

Penyajian data mengenai jenjang pendidikan ini merupakan aspek yang paling mudah dalam memberikan gambaran untuk mengukur tingkat pendidikan sumber daya manusia atau penduduk di suatu wilayah. Kegiatan pendidikan dapat berjalan dengan baik apabila sarana dan prasarananya memadai. Desa Mekarwangi memiliki sarana pendidikan yang terdiri atas 8 buah Taman Kanak-Kanak/PAUD, 4 Sekolah Dasar, 2 Sekolah Menengah Pertama, 1 buah Sekolah Menengah Kejuruan. Mayoritas penduduk Desa Mekarwangi sebesar $20 \%$ telah menyelesaikan program wajib belajar 9 tahun hal ini dapat terlihat dengan hadirnya fasilitas pendidikan berupa SD dan SMP.

\section{c. Penduduk Berdasarkan Mata Pencaharian}

Desa Mekarwangi memiliki mata pencaharian yang bervariasi, Total penduduk yang bekerja di 9 sektor dengan umur produktif ini mencapai 4.503 jiwa. Data mata pencaharian ini merupakan data demografi yang mampu menunjang peneliti dalam memetakan aktivitas ekonomi yang menjadi sektor penopang dalam memenuhi kebutuhan masyarakat sehari-hari. Total akumulasi penjumlahan antara petani dan buruh tani mencapai 1.070 orang, disusul oleh karyawan swasta dengan angka 908 pekerja.

\section{B. Karakteristik Informan}

Karakteristik informan merupakan aspek penting dalam proses penyusunan hasil penelitian. Hal ini penting diperhatikan karena untuk menjawab pertanyaan dalam pedoman wawancara diperlukan informasi yang sesuai dengan tujuan penelitian sehingga peneliti mampu menggali dan melakukan proses tanya jawab secara mendalam serta menyeluruh. Secara spesifik karakteristik informan dikelompokan berdasarkan umur, pekerjaan, dan tingkat pendidikan. 


\section{Deskripsi Perilaku Petani dalam Berusahatani Padi Organik di Era Covid-19}

Hadirnya Covid-19 di Indonesia menyebabkan berbagai permasalahan, baik pada sektor ekonomi, sosial, kesehatan, dan lain-lain. Para pelaku ekonomi baik pada tingkat konsumen, produsen dan distributor mengalami perubahan-perubahan dalam berperilaku. Pada tingkat produsen yaitu petani, perubahan yang terjadi di pasar menyebabkan dampak-dampak tertentu. Petani padi organik di Desa Mekarwangi tepatnya kelompok tani Cidahu yang tergabung dalam Gapoktan Simpatik merasakan perubahan-perubahan dalam aktivitas bertani dan berperilaku dalam memenuhi kebutuhan. Perubahan tersebut dapat dilihat dari berbagai karakteristik yang mampu menunjukkan tindakan apa saja yang dilakukan dalam berusaha tani padi organik di tengah pandemi.

Tabel 2 Karakteristik Informan

\begin{tabular}{clclccc}
\hline No. & \multicolumn{1}{c}{ Nama } & $\begin{array}{c}\text { Umur } \\
\text { (tahun })\end{array}$ & \multicolumn{1}{c}{ Pekerjaan } & Pendidikan & Status & $\begin{array}{c}\text { Luasan Lahan } \\
\left(\mathrm{m}^{2}\right)\end{array}$ \\
\hline 1. & Agus Farid & 29 & Petani Penggarap & SMA & Menikah & 980 \\
2. & Mustofa & 46 & Petani Penggarap & SD & Menikah & 4.480 \\
3. & Syakur & 51 & Petani Pemilik & SD & Menikah & 686 \\
4. & Deden & & Petani Penggarap & SD & Menikah & 1.680 \\
\hline
\end{tabular}

Secara singkat salah satu informan menjelaskan mengenai proses budidaya padi organik di kampung cidahu, menurut penuturannya bertanam padi secara organik sama dengan bertanam padi konvensional, hal yang membedakannya adalah varietas benih, penggunaan pupuk dan pestisida yang digunakan.

\section{Aktivitas Budidaya Padi Organik di Era Covid-19}

\section{Varietas}

Kelompok Tani Cidahu mengambil pilihan yang berbeda-beda saat memutuskan varietas yang akan ditanam. Berdasarkan hasil wawancara informan 1 yaitu Kang Agus memilih untuk menanam Varietas Sintandur pada musim pertama, selanjutnya pada musim kedua menanam padi hitam, karena dalam satu tahun terdiri atas 2,5 musim, pada setengah musim terakhir beliau menanam varietas padi merah. Alasan kang Agus menanam varietas-varietas tersebut karena didasari oleh preferensi kebutuhan. Pemilihan varietas Sintandur biasanya didasari bahwa persediaan beras di rumah sudah berkurang sehingga ketika menanam Sintandur sebagian hasilnya dapat dijual dan sebagian lainnya dapat dikonsumsi. Informan 
lainnya mengatakan bahwa varietas merah dan hitam hampir tidak pernah mereka konsumsi untuk memenuhi kebutuhan pangan rumah tangga, karena kedua varietas tersebut memiliki harga jual yang tinggi sehingga kebutuhan beras dapat disubstitusi dari hasil penjualan kedua varietas tersebut dengan membeli beras biasa.

\section{Penyiapan Lahan}

Pada pertanian organik proses ini cukup penting untuk mendapatkan hasil produksi yang optimal. Alat yang digunakan dalam proses penyiapan lahan adalah traktor untuk membantu memecahkan bongkahan tanah sawah hingga menjadi lunak dan halus. Selain itu, persiapan ketersediaan air harus diperhatikan. Proses penyiapan lahan oleh Kelompok Tani Cidahu tidak mengalami perubahan, karena menurut informan akitivitas ini dapat berjalan seperti biasa dengan ada dan tidaknya pandemi Covid-19 sehingga tidak ada aktivitas yang berubah dan tidak ada penyesuaian baru yang dilakukan.

\section{Penanaman}

Sistem penanaman yang dilakukan adalah Tapin yaitu tanam pindah, dimana pembibitan dilakukan di tempat terpisah selama 10 hari baru bibit dipindahkan ke lahan sawah. Berdasarkan penuturan dari semua informan, saat proses penanaman setelah musim sebelumnya tidak ada aktivitas yang berubah, hanya saja Poktan Cidahu harus menunggu lebih lama untuk mendapatkan benih, dikarenakan Gapoktan Simpatik tidak memiliki persediaan stok benih dan harus menunggu pengiriman dari Kota Subang. Alasan Poktan Cidahu tidak menggunakan benih dari hasil sortasi panen karena standar kualitas benihnya sudah menurun atau tidak bagus lagi, hal ini terlihat dari penyematan label benih berwarna ungu, putih dan biru, jika warna sudah mencapai level warna putih artinya sudah tidak bisa dipakai lagi.

"kemaren sempet sih nunggu benih
agak lama, karena simpatik
penjualannya lagi menurun dan
gapunya uang, jadi gapunya stok.
Terus lagi biasanya beli ke Subang
tapi karna PSBB waktu itu jadi harus
nunggu buat dapet benihnya"

\section{Pemupukan}

Pada padi konvensional pupuk yang digunakan adalah pupuk anorganik yang biasanya terdiri atas Urea, SP-26, dan KCL dengan dosis tertentu. Sedangkan untuk padi organik pupuk yang digunakan berasal dari pupuk kendang, kompos, sisa tanaman jerami dan lain-lain. Pupuk kompos didapatkan oleh petani dengan cara membeli ke Gapoktan Simpatik dengan sistem kredit, 
dimana petani mengambil terlebih dahulu pupuk yang akan digunakan dan pembayaran dilakukan saat panen. Harga pupuk kompos yang dijual terbilang murah dengan harga per kilo Rp500Rp700. Untuk lahan seluad $980 \mathrm{~m}^{2}$ pupuk yang digunakan sebanyak $2 \mathrm{~kg}$.

"kalau pupuk mah kita gakesulitan karna disediakan oleh Gapoktan Simpatik, jadi nanti kita ngambil dulu terus dibayarnya nanti pas udah panen"

Pupuk cair berupa MOL juga diberikan kepada tanaman padi organik oleh Poktan Cidahu, hal ini karena menurut penuturan informan pemberian MOL didasari bahwa larutan ini mengandung unsur hara mikro dan makro. Selain itu, juga mengandung bakteri yang mampu merombak bahan organik dalam tanah, merangsang pertumbuhan tanaman dan mampu menjadi agen pengendali hama penyakit tanaman. Pada kegiatan pemberian pupuk kompos dan penyemprotan MOL, informan mengatakan bahwa tidak ada yang berubah, dikarenakan aktivitas dapat berjalan seperti biasa tanpa terganggu dengan adanya Pandemi Covid-19.

\section{Penyiangan}

Penyiangan penting dilakukan karena salah satu kendala dalam budidaya padi organik adalah keberadaan gulma yang akan menghambat tanaman untuk memproduksi hasil yang optimal. Pada aktivitas ini petani penggarap tidak melakukan penyiangan secara langsung melainkan mempekerjakan 4 buruh tani yang semuanya terdiri atas ibu-ibu, salah satunya adalah Ibu Mpon. Beliau mengatakan bahwa saat era pandemi Covid-19, aktivitas untuk melakukan penyiangan tidak ada yang berubah, karena kegiatan dapat dilakukan seperti biasa, tidak ada batasan aktivitas yang dianjurkan dalam beraktivitas usahatani oleh pemerintah setempat.

\section{Pengairan}

Terdapat dua proses pengairan sawah, yang pertama adalah penggenangan air, hal ini dilakukan untuk menjaga produktivitas dan pertumbuhan tanaman supaya menjadi lebih baik. Proses kedua adalah pengiringan sawah, hal ini dilakukan saat fase pemasakan biji.

Saat Pandemi Covid-19 bertepatan dengan keadaan cuaca yang tidak stabil, hal ini ditandai dengan kekeringan yang terjadi di Kampung Cidahu. Irigasi yang digunakan hanya mengandalkan air hujan, sehingga proses pengairan bergantung pada kondisi cuaca. Saat proses penanaman yang dilakukan pada bulan September petani mengalami 
kesulitan dalam memperoleh air, sehingga hasil panen yang didapatkan tidak seoptimal dari bulan-bulan sebelumnya.

\section{Pengendalian Hama dan Penyakit}

Pada budidaya padi organik pengendalian hama penyakit tanaman dilakukan dengan menerapkan konsep pengendalian hama terpadu. Pemilihan MOL selain sebagai pemberi nutrisi bagi tanaman padi, petani Cidahu menjadikan MOL sebagai pengendali hama dan penyakit. Kandungan bahan organik yang terdapat dalam MOL diyakini mampu mengurangi tanaman dari terserang hama dan penyakit. Proses pemberian MOL ini dapat berjalan seperti biasa dan tidak terganggu dengan adanya Pandemi Covid-19, sehingga aktivitas dapat dilakukan seperti biasa.

\section{Panen dan Pasca Panen}

Proses panen dan pasca panen pada tanaman padi organik tidak jauh berbeda dengan pemanenan padi konvensional. Waktu panen padi tergantung dari varietas yang ditanam, apabila menanam padi putih dan merah dapat dipanen setelah 110-115 hari, sedangkan untuk padi hitam dapat dipanen setelah 4 bulan, karena memiliki waktu tanam yang lebih lama.
Pada waktu tertentu petani padi cidahu akan melakukan penimbunan gabah untuk dijual karena dengan melakukan penimbunan akan memberikan penghasilan yang lebih dan bisa dijual saat permintaan sedang tinggi. Namun karena adanya Pandemi Covid-19 penimbunan tidak dapat dilakukan karena permintaan pun sangat terbatas.

"boro-boro ditimbun neng, kemaren juga hasil lagi ga banyak. Mending dijual sama sebagiannya di makan aja, daripada ditimbun ga kejual"

\section{E. Kondisi Sertifikasi}

Secara definisi berdasarkan SNI 6729:2013 organik adalah istilah pelabelan yang menyatakan suatu produk telah melalui proses produksi sesuai dengan kaidah sistem pertanian organik dan mendapatkan pengakuan melalui proses sertifikasi oleh Lembaga sertifikasi organik resmi. LSO (Lembaga Sertifikasi Organik) merupakan Lembaga yang bertanggung jawab untuk melakukan sertifikasi pelabelan organik dan secara resmi terakreditasi menurut Standar Nasional Indonesia dan Komite Akreditasi Nasional.

Sertifikasi padi organik yang digunakan Gapoktan Simpatik berubah sebanyak empat kali, saat masih melakukan ekspor sertifikasi yang digunakan adalah sertifikasi internasional 
yaitu IMO (Institure for Marketology) yang berasal dari Swiss dan EU (Eropa Union) yang berasal dari negara-negara di benua Eropa. Sertifikasi nasional yang pernah dan sedang digunakan adalah BioCert dan INOFICE.

Sertifikasi padi organik yang digunakan Gapoktan Simpatik berubah sebanyak empat kali, saat masih melakukan ekspor sertifikasi yang digunakan adalah sertifikasi internasional yaitu IMO (Institure for Marketology) yang berasal dari Swiss dan EU (Eropa Union) yang berasal dari negara-negara di benua Eropa. Sertifikasi nasional yang pernah dan sedang digunakan adalah BioCert dan INOFICE. Kelompok tani yang menggunakan sertifikasi organik berkurang, karena biaya sertifikasi yang mahal dan daya serap pasar sedang menurun, sehingga saat ini sertifikasi yang digunakan adalah INOFICE yang hanya diterapkan kepada 2 poktan dengan pembagiannya yaitu Cidahu dan Mekarkarya.

\section{F. Kondisi Ekspor}

Penjualan beras organik ke pasar ekspor sejak tahun 2019 terus mengalami penurunan dan ekspor terakhir bulan Januari tahun 2019, hingga saat ini Gapoktan Simpatik belum melakukan ekspor lagi. Kondisi ini mempengaruhi motivasi petani dalam memproduksi padi organik, karena permintaan menurun sejak tidak melakukan ekspor dan gabah petani tidak selalu dibeli oleh Gapoktan Simpatik sehingga petani mengalami kesulitan dalam menjual hasil produksi. Sebelum adanya Pandemi Covid-19 permintaan sudah cukup menurun dibandingkan saat masih melakukan ekspor, terlebih dengan hadirnya Covid19 serapan pasar domestik cukup sedikit

"sekarang mah susah neng, pas taun kemaren terakhir ekspor Simpatik jarang beli banyak, seperlunya aja weh, kadang di anjuk eta ge dicicil bayarna teh"

\section{G. Kondisi Pemasaran}

Poktan Cidahu memasarkan produk pertaniannya secara mandiri, selain dengan adanya kontrak yang disepakati oleh Poktan Cidahu dan Gapoktan Simpatik mengenai penjualan beras organik, petani diberi kebebasan dalam menentukan penjualan hasil produksinya. Hubungan Poktan Cidahu dan Gapoktan Simpatik adalah mitra, sehingga kontrak yang berlaku tidaklah terlalu mengikat, apabila Gapoktan Simpatik ingin membeli hasil dari Poktan Cidahu akan ada kesepakatan terlebih dahulu, dan begitu pun sebaliknya.

Kondisi permintaan dari Gapoktan Simpatik yang terbatas menyebabkan petani harus mencari pembeli lain yang 
mampu menampung hasil gabahnya. Selain itu, saat pandemi Covid-19 daya serap dan daya beli Gapoktan Simpatik menurun menyebabkan pembelian yang dilakukan Gapoktan Simpatik kepada petani Cidahu dilakukan dengan sistem pembayaran kredit, karena pembayaran yang dilakukan oleh Gapoktan Simpatik harus menunggu pelunasan dari pihak ketiga.

Ketidakpastian permintaan menyebabkan kebingungan pada petani, sehingga petani harus melakukan tindakan-tindakan yang meminimalisir kerugian dari memproduksi padi organik di tengah Pandemi Covid-19.

"saya mah gatau kalau dipasar
kondisinya gimana, pokonya mah
pembeli kita ya Simpatik sama
tengkulak lainnya, yang kerasa beda
mah pas udah ga ekspor lagi neng,
makin dikit mintanya, terus ditambah
sekarang lagi pandemi, makin dikit
simpatik mintanya. Jadi harus jual ke
yang lain neng da ngandelin mah
gabisa."

\section{H. Kondisi Hubungan Sosial}

Berdasarkan teori Scott mengenai Patron-Klien menjelaskan bahwa hubungan khusus antara dua orang yang melibatkan persahabatan instrumental, dimana seseorang yang memiliki status ekonomi lebih tinggi disebut sebagai Patron sedangkan individu yang memiliki status sosial ekonomi lebih rendah disebut sebagai Klien.
Pada kasus kelompok tani Cidahu yang melakukan kemitraan dengan Gapoktan Simpatik dapat terlihat bahwa sifat hubungan Patron-Klien tersebut berbentuk vertikal, karena Kelompok Tani Cidahu menjalin kemitraan dengan Gapoktan Simpatik selaku prosesor dengan melalui kontrak. Pola kemitraan yang dilakukan bersifat formal yang memiliki perjanjian tertulis dan non formal yang tidak memiliki perjanjian secara tertulis. Kelompok tani pada hubungan formal ini berperan sebagai penyedia tetap beras organik yang selalu melakukan pembaharuan setiap tahun.

Meskipun telah terdapat perjanjian yang bersifat formal dalam transaksi jual beli padi organik, namun secara realitas serapan pasar beras organik pada tingkat konsumen tidaklah mampu memenuhi hasil produksi petani, sehingga kemitraan formal tidak menjamin terserapnya pasar secara menyeluruh. Hal ini terjadi karena terbatasnya akses pasar dan sumber daya modal yang dimiliki oleh industri pengolahan atau dalam kasus ini adalah Gapoktan Simpatik, sehingga diperlukan upaya-upaya untuk menjangkau akses pasar yang lebih luas melalui berbagai pemanfaatan sumber daya. Keadaan ini memberikan dampak kepada hubungan petani dengan Gapoktan Simpatik, 
dimana petani mengalami penurunan motivasi dalam memproduksi padi organik.

"aduh neng pas ekspor mah meni bungah da mun sateuacan panen teh sok di DP an heula ku Simpatik, jadi kan abdi the gaduh cecepengan kanggo kaperlua nu lain, baheula mah sok aya pinjaman $t i$ Simpatik kanggo patani-patani nu butuh, ayeuna mah boro-boro neng. Mun panen ge sok dicicil, mending di cicil na teh dua atawa tilu kali cicilan, ieu mah teu aya kapastian, sa dipasihna weh $k u$ simpatik. Komodeui pas pandemi kieu neng, kadang mun panen di peser kadang teu dipeser sama sekali, jadi leuwih karasa neng"

\section{Faktor Penghambat Kegiatan Usahatani Padi Organik di Era Covid-19}

\section{Akses Memperoleh Benih}

Pandemi Covid-19 telah menghambat proses distribusi secara umum, termasuk bidang pertanian. Pada saat penerapan kebijakan PSBB (Pembatasan Sosial Berskala Besar) di Kota Subang, Gapoktan Simpatik kesulitan dalam melakukan pembelian benih sehingga berdampak pada kelangkaan benih di tingkat petani. Hal inilah yang menyebabkan petani harus menunggu distribusi benih dari Gapoktan Simpatik yang berakibat pada penundaan waktu tanam oleh petani.

\section{Sistem Pembayaran}

Kondisi perekonomian masyarakat saat ini berada ditingkat yang memprihatinkan, hal ini tentunya disebabkan oleh Pandemi Covid-19 yang memberikan perubahan pada segala aspek kehidupan baik ekonomi, sosial, kesehatan dan lain-lain. Penurunan pendapatan pada aktivitas ekonomi memberikan dampak kepada Gapoktan Simpatik selaku pelaku usaha yang menaungi petani dalam membantu memasarkan padi organik. Poktan Cidahu yang menjual hasil produksi kepada Gapoktan Simpatik harus menyepakati pembayaran yang dilakukan secara kredit. Dampaknya adalah petani harus mengatur keuangan rumah tangga dan keuangan untuk biaya produksi padi organik kembali pada musim tanam yang akan datang dan ketidakpastian dalam waktu pembayaran.

\section{Penyerapan Hasil Produksi}

Penurunan pendapatan yang diakibatkan dari penurunan pertumbuhan ekonomi membawa dampak pada daya beli masyarakat. Hal serupa terjadi pada petani padi organik Cidahu, dimana permintaan dari Gapoktan Simpatik menurun secara drastis yang menyebabkan petani memiliki kelebihan supply sehingga petani harus menentukan 
tindakan dalam menentukan pilihan hasil produksi padi organik tersebut dikonsumsi atau mencari pengepul lain.

\section{Penurunan Harga Jual Gabah}

Mata rantai distribusi pertanian memiliki alur yang panjang serta melalui berbagai pihak. Salah satu pihak yang terlibat adalah keberadaan tengkulak yang membantu petani dalam memasarkan produk melalui modal jaringan sosial. Pada kondisi ini Poktan Cidahu mengalami dilema dari keberadaan tengkulak, dengan kondisi ketidakpastian dan penurunan permintaan gabah dari Gapoktan Simpatik, tengkulak hadir memberikan penyelesaian solusi berupa melakukan pembelian kepada petani dalam jumlah tertentu sesuai yang dibutuhkan. Namun, pada sisi lain tingkat harga yang dibeli oleh tengkulak jauh berada di bawah harga standar yang Gapoktan Simpatik biasa beli. Hal ini lah yang menyebabkan petani dilema dalam memproduksi padi organik di tengah pandemi.

\section{J. Strategi Aktif}

Strategi aktif menurut Edi Suharto diartikan sebagai suatu strategi yang melakukan optimalisasi segala potensi keluarga untuk meningkatkan sumber pendapatan keluarga dalam rangka pemenuhan kebutuhan hidup.

\section{Pembagian Kerja}

Dalam rangka melakukan pemenuhan kebutuhan rumah tangga terdapat dua informan yang melakukan pembagian kerja dengan istri sebagai upaya untuk menambah sumber penghasilan. Pembagian kerja yang dilakukan adalah istri Pak Mustofa membantu untuk menggarap lahan sawah milik suaminya. Strategi berbeda dipilih oleh Pak Deden beliau bekerja sama dengan istri untuk melakukan pemenuhan kebutuhan hidup dengan cara meminta istri untuk mencarikan dana tambahan melalui lembaga keuangan non formal atau yang biasa disebut sebagai rentenir. Dua informan lainnya tidak melakukan pembagian kerja dengan anggota keluarga lainnya dikarenakan secara individu mereka masih mampu mengusahakan penambahan pendapatan dari sektor lain dan memanfaatkan sumber daya lain yang tersedia, bukan berbentuk tenaga kerja.

\section{Memanfaatkan Penghasilan dari} Sektor Non Usahatani Padi Organik

Berdasarkan penuturan yang disampaikan oleh informan, semua informan sepakat bahwa sektor pertanian bukanlah menjadi sektor utama dalam memenuhi kebutuhan sehari-hari. 
Penghasilan yang terbatas dari hasil menanam padi organik tidaklah mampu memenuhi segala keperluan rumah tangga, sehingga informan menyiasati hal tersebut dengan mencari sumber pendapatan lain dari sektor non usaha tani.

Kebutuhan di uar pangan realitanya menyebabkan permasalahan dalam situasi sosial rumah tangga sehingga Pak Agus mencari pekerjaan lain sebagai surveyor lapangan suatu produk untuk melakukan riset pasar perusahaan rokok. Strategi lain yang dipilih oleh informan 2 yaitu Pak Mustofa untuk meningkatkan pendapatan adalah dengan memanfaatkan ternak yang dimiliki di rumah dan mencari pekerjaan lain namun masih di sektor usahatani yaitu dengan menjadi buruh untuk menggarap kebun jagung milik orang lain. Pada saat perekenomian keluarga sedang stabil Pak Mustofa memutuskan untuk beternak domba yang berjumlah 7 ekor. Upah yang diberikan pemilik kebun jagung dengan waktu kerja sistem sabedug yaitu dari pagi sampai dzuhur sebesar Rp45.000. Berdasarkan penuturan beliau, Pak Mustofa lebih merasa untung untuk bekerja di sawah daripada bekerja sebagai buruh di kebun jagung, namun kondisi ini memaksa Pak Mustofa untuk menambah penghasilan lain dari kebun jagung. Selain itu, Pak Mustofa memiliki ternak, hal ini memberikan pemasukan lebih di tengah kondisi pandemi, ternak-ternak ini mampu membantu peningkatan penghasilan Pak Mustofa dalam memenuhi kebutuhan. Selain beternak, Pak Mustofa mengatakan bahwa hasil beternak cukup mampu membantu perekonomian keluarga namun cash flow dari beternak tidak terlalu cepat, sehingga bekerja di kebun jagung menjadi salah satu cara Pak Mustofa untuk memenuhi kebutuhan sehari-hari.

Strategi berbeda dipilih oleh oleh Mang Deden. Mang Deden harus bekerja di sektor lain yaitu sebagai Operator di CV Alam Subur. Meskipun di tengah Pandemi ini CV Alam Subur mengalami penurunan pemasukan sehingga mengakibatkan keterlambatan dalam memberikan gaji, namun Mang Deden memiliki strategi lain disamping memanfaatkan penghasilan dari usahatani, sehingga tidak hanya bergantung pada penjualan hasil produksi padi organik.

Informan keempat yaitu Pak Syakur memiliki strategi berbeda dengan memanfaatkan penghasilan dari hasil pensiunan. Kondisi permintaan Simpatik yang menurun menyebabkan Pak Syakur 
tidak memprioritaskan hasil penjualan beras organik ke Simpatik sebagai penghasilan utama.

\section{K. Strategi Pasif}

Strategi pasif merupakan strategi yang dilakukan dengan cara mengurangi pengeluaran keluarga seperti pengeluaran biaya untuk sandang, pangan, transportasi, Pendidikan, biaya sosial dan kebutuhan lainnya. Strategi ini dapat diartikan sebagai strategi yang memprioritaskan kebutuhan pokok atau primer untuk bertahan hidup di tengah perubahan kondisi ekonomi keluarga.

\section{Penekanan Pengeluaran Rumah Tangga}

Melalui strategi ini keluarga petani dituntut harus menyusun kebutuhan berdasarkan skala prioritasnya. Salah satu informan yaitu Pak Agus mengatakan bahwa sang istri membantu untuk mengelola keuangan dalam rangka menyusun anggaran pengeluaran rumah tangga, selama pandemi ini Pak Agus dan istri lebih berhati hati dalam melakukan pengeluaran. Hal serupa juga dilakukan oleh Pak Mustofa yang melakukan penekanan pengeluaran rumah tangga dengan cara memprioritaskan kebutuhan pangan dan biaya kesehatan, keputusan mengenai biaya kesehatan hal yang diprioritaskan didasari bahwa kondisi istri Pak Mustofa yang sedang hamil sehingga kebutuhan mengenai nutrisi dan kesehatan saat kehamilan menjadi sesuatu yang penting dilakukan di tengah kondisi Pandemi ini. Informan ketiga yaitu Mang Deden mengatakan bahwa dampak pandemi ini memberikan perubahan kondisi ekonomi keluarga, dimana pemasukan tetap tidak lagi mampu memenuhi kebutuhan meskipun terdapat penghasilan dari hasil produksi padi organik namun tetap tidak bisa memenuhi kebutuhan secara maksimal sehingga selain meminta bantuan pada lembaga keuangan non formal Mang Deden dibantu istri untuk menekan pengeluaran dengan memprioritaskan kebutuhan pangan pokok dan kebutuhan pendidikan anak, dikarenakan memiliki 2 tanggungan anak yang masih menempuh pendidikan secara online sehingga diperlukan pengeluaran tambahan untuk membeli kuota internet untuk anak.

\section{Mengonsumsi Hasil Usahatani}

Berdasarkan penuturan hasil wawancara yang dilakukan pada salah satu informan yaitu Pak Agus strategi ini dipilih untuk mengurangi dan menekan pengeluaran budget untuk beras. Beliau mengatakan bahwa pengluaran untuk beras dirasa cukup besar sehingga dengan memanfaatkan hasil usahatani mampu 
memberikan dampak yang signifikan dalam menekan pengeluaran dan dapat dialokasikan pada kebutuhan lain.

Strategi ini dilakukan oleh semua informan mereka menyepakati bahwa padi organik yang dikonsumsi adalah yang berjenis varietas putih bukan yang merah dan hitam, karena untuk tingkat konsumsi rumah tangga masing-masing informan tidak mempermasalahkan jenis beras apa yang dikonsumsi selama hal tersebut dapat terpenuhi dengan baik. Kondisi Pandemi Covid-19 memberikan perubahan terhadap jumlah beras organik yang dikonsumsi, saat ini proporsi penjualan beras organik dan beras organik yang dikonsumsi rumah tangga lebih tinggi dialokasikan untuk pemenuhan konsumsi rumah tangga.

\section{Strategi Jaringan}

Secara singkat strategi jaringan dapat didefinisikan sebagai strategi yang dilakukan petani dengan memanfaatkan relasi sosial baik yang bersifat formal maupun informal. Kegiatan pemanfaatan ini dapat dilihat dari tindakan yang dipilih seperti meminjam uang kepada tetangga dan kerabat, mengutang di warung atau retail kecil, memanfaatkan bantuan sosial, meminjam uang kepada lembaga nonformal seperti rentenir/tauke, meminjam uang kepada lembaga keuangan formal seperti bank, dan lainlain.

\section{Meminjam Uang kepada Lembaga \\ Formal dan Nonformal}

Kondisi Pandemi Covid-19 telah memaksa petani untuk mencari sumber pendapatan lain di luar sumber pendapatan yang dihasilkan dari strategi aktif dan pasif. Tekanan ini membuat petani mau tidak mau harus menambah pemasukan melalui pinjaman melalui lembaga keuangan formal yaitu bank dan lembaga keuangan nonformal seperti renternir.

\section{Meminjam Uang kepada Tetangga}

Jaringan tetangga merupakan sumberdaya yang paling berdampak pada kehidupan sosial ekonomi keluarga petani, pasalnya tingkat solidaritas sosial masyarakat kampung Cidahu masih kental dan terikat. Berdasarkan hasil wawancara yang dilakukan kepada empat informan semua sepakat bahwa di tengah pandemi ini bantuan tetangga menjadi sesuatu yang sangat berharga. Pinjaman yang dilakukan informan kepada tetangga ini tidak memliki jaminan tertentu, hanya bermodalkan kepercayaan.

\section{Memanfaatkan Bantuan Sosial Pemerintah}

Bentuk bantuan yang diberikan pemerintah ini adalah bantuan sembako, 
bantuan sosial tunai, BLT dana desa, Listri gratis, kartu prakerja, dan BLT usaha mikro. Penerima bantuan dikelompokan berdasarkan spesifikasi yang paling sesuai dengan kategori bantuan. Berdasarkan informasi dari salah satu informan bahwa hampir semua warga di kampung Cidahu menerima bantuan sosial dari pemerintah. Hal ini membuktikan bahwa berdasarkan data petani termasuk dalam kelompok rentan yang memerlukan bantuan sosial. Keempat informan mengatakan bahwa dengan adanya bantuan sosial ini memberikan tambahan penghasilan yang cukup meskipun jumlahnya tidak terlalu besar dan waktu yang diberikan juga tentative, namun mampu memberikan dampak yang berbeda pada kondisi ekonomi keluarga.

\section{Strategi Aktivitas Lapangan}

Perubahan yang dirasakan petani tidak hanya terjadi pada strategi pemenuhan kebutuhannya saja, melainkan pada aktivitas agribisnis di lapangan. Agribisnis diartikan sebagai kegiatan yang berhubungan dengan penanganan komoditi pertanian yang secara kompleks meliputi kegiatan pengadaan sarana produksi, pengolahan hasil, dan pemasaran yang memiliki keterkaitan dengan pertanian dalam arti luas yaitu usaha yang menunjukan kegiatan pertanian (Arsyad dkk, 2006).

1. Penyesuaian Varietas yang

Ditanam dan Menunggu

\section{Ketersediaan Benih}

Tujuan dari strategi ini dilakukan adalah untuk memilih varietas yang paling tepat ditanam saat terjadi perubahan kondisi penjualan hasil produksi. Strategi ini dilakukan dengan cara menganalisis kelebihan dan kekurangan dari penggunaan varietas tertentu agar sesuai dengan kondisi yang terjadi saat ini.

\section{Menjual Hasil Produksi ke Tengkulak}

Tindakan yang dipilih petani dalam memastikan penanaman padi organik memberikan keuntungan dan mampu menambah penghasilan adalah dengan menjual hasil produksi tersebut kepada pengumpul atau yang biaa disebut sebagai tengkulak.

\section{Pembahasan}

Teori yang disampaikan oleh James Scott dalam bukunya yang berjudul "The Moral Economy of The Peasant" yang menyatakan bahwa petani pada dasarnya mendahulukan mencari keselamatan dan meminimalkan factor risiko yang terjadi. Pada saat petani mengalami suatu kondisi krisis dan petadi berada di posisi 
terhimpit oleh suatu keadaaan yang menyulitkan mereka akan lebih mengutamakan atau mendahulukan untuk mencari keselamatan.

Scott memiliki pandangan bahwa moral ekonomi petani didasari dari adanya etika subsistensi dan norma resiporitas. Karakteristik ini terlihat dari tindakan petani yang melakukan konsumsi hasil produksinya untuk melakukan pemenuhan kebutuhan pangan keluarga. Pada kondisi ini petani berada dalam posisi yang paling rentan dimana petani harus tetap melakukan budidaya padi organik untuk menjaga eksistensi dan memenuhi permintaan di tengah ketidakpastian, dan pada sisi lain petani harus tetap memberi nafkah keluarga untuk melakukan pemenuhan keluarga.

Bedasarkan teori yang disampaikan oleh Popkin dalam buku yang berjudul "The Rational Peasant" yang mengatakan bahwa dengan dasar perhitungan rasional indvidu petani memiliki cara yang beragam dalam menentukan Tindakan dalam mengadapi perubahan situasi. Dalam teori ini Popkin berpendapat bahwa petani dipandang sebagai individu yang memiliki kemampuan memilih untuk memaksimalkan fasilitas dan sumberdaya yang tersedia. Oleh karena itu, individu yaitu petani selalu memaksimalkan pilihannya sehingga dengan pilihan tersebut individu tersebut dapat menguntungkan dirinya. Tindakan atau strategi terbagi menjadi empat yaitu strategi aktif, strategi pasif, strategi jaringan, dan strategi aktivitas lapangan. Hal ini menunjukan pertimbangan rasional yang dilakukan petani untuk mengambil tindakan bedasarkan pertimbangan keuntungan yang diperoleh petani.

Hayami dan Kikuchi menggunakan perpaduan antara Teori Scott dan Popkin, namun mereka menyatakan bahwa kecenderungan masyarakat petani pada dasarnya adalah tolong menolong pada kondisi aras subsistensi, tetapi petani juga menganut pemikiran rasionalitas petani

\section{KESIMPULAN DAN SARAN}

\section{Kesimpulan}

Kelompok Tani Cidahu merupakan salah satu kelompok tani yang tergabung dalam Gapoktan Simpatik. Budidaya utama yang dilakukan adalah budidaya padi organik yang mulai dilakukan sejak tahun 2005. Kelompok tani ini memberikan cukup prestasi dengan memberikan kontribusi dalam hasil produksi yang pasarkan di pasar ekspor dan domestik. Kemampuan ekspor ini 
memberikan motivasi kepada petani untuk membudidayakan padi organik.

Namun, seiring berjalannya waktu terjadi permasalahan dalam kemampuan ekspor dari Gapoktan Simpatik yang semakin menurun sehingga kelompok tani yang masih dalam naungan sertifikasi nasional semakin berkurang. Hal ini diperparah dengan hadirnya Pandemi Covid-19 yang menyebabkan beberapa perubahan dalam kondisi pemenuhan kebutuhan rumah tangga petani, karena Covid-19 berdampak langsung pada aktivitas dan kondisi permintaan terhadap beras organik kepada Kelompok Tani Cidahu.

Pilihan tindakan yang dilakukan oleh petani didasari bahwa petani merupakan kelompok subsisten yang sangat rentan berada dalam batas garis subsistensi, hal ini sesuai dengan teori yang disampaikan oleh James Scott. Tindakan yang dipilih petani dalam menentukan strategi adaptasi didasari oleh teori Popkin yang menyatakan dalam buku yang berjudul "The Rational Peasant" mengatakan bahwa dengan dasar perhitungan rasional indvidu petani memiliki cara yang beragam dalam menentukan tindakan dalam menghadapi perubahan situasi. Petani Kampung Cidahu menerapkan strategi sesuai dengan teori yang disampaikan oleh Edi Suharto yang membagi strategi adaptasi bertahan hidup petani dibagi menjadi 3 yaitu strategi aktif, pasif, jaringan dan strategi aktivitas lapangan.

\section{Saran}

1. Kelembagaan formal yang terdapat di Kampung Cidahu yaitu Gapoktan Simpatik yang sekaligus menjadi mitra dari petani yang tergabung dalam kelompok tani Cidahu diharapkan mampu memperluas jaringan pasar untuk memberikan alternatif lain bagi petani dalam menjual hasil produksi padi organik, sehingga petani mampu meminimalisir kerugian dengan menjual padi organi ke lembaga non formal seperti tengkulak.

2. Perlu adanya pendampingan mengenai alokasi bantuan sosial yang diberikan oleh pemerintah sehingga petani mampu memetakan penggunaan dana bantuan sosial yang terarah dalam melakukan pemenuhan kebutuhan hidup keluarga.

3. Ketersediaan pasar yang terbatas dalam memasarkan produk padi organik menjadi permasalahan petani saat ini sehingga diharapkan ada keterlibatan dari pemerintah dan 
stakeholder terkait dalam membantu petani dalam memperluas pasar.

\section{DAFTAR PUSTAKA}

Cavan, S. (1977). Investigative Social Research: Individual and Team Field Research. Jack D. Douglas . American Journal of Sociology, 83(3), 809-811. https://doi.org/10.1086/226628

Istiqomah, A., Nindyantoro, N., \& Novindra, N. (2019). Analisis Land Rent dan Daya Saing Pertanian Padi Organik Di Kabupaten Tasikmalaya. Journal of Agriculture, Resource and Environmental Economics, 2(1), 13-25.

https://doi.org/10.29244/jaree.v2i1. 25929
Setiawan, J. (2015). Pemasaran Karet( Kajian Struktur, Perilaku, dan Penampilan Pasar) di Kabupaten Kuantan Singingi Provinsi Riau. Jom Faperta, 2, 6.

Sugiyono. (2016). Metode Penelitian Kuantitatif Kualitatif dan $R \& D$. Alfabeta. 